\title{
Synthesis of $\beta$-SiAION Whiskers from Pyrophyllite
}

\author{
Jingkun YU, Satoru UENO, Keisuke HIRAGUSHI, Shaowei ZHANG* and Akira YAMAGUCHI* \\ Okayama Ceramics Research Foundation, 1406-18, Nishikatakami, Bizen-shi 705 \\ *Department of Materials Science and Engineering, Nagoya Institute of Technology, Gokiso-cho, Showa-ku, Nagoya-shi 466
}

\author{
ろう石による $\beta$-SiAION の合成 \\ 于 景坤・上野 覚・平櫛敬資・張 少偉*。山口明良* \\ 岡山セラミックス技術振興財団，705 備前市西片上 1406-18 \\ *名古屋工業大学工学部村料工学科, 466 名古屋市昭和区御器所町
}

\begin{abstract}
Beta-SiAlON whiskers were synthesized by heating the admixture of pyrophyllite and resin at 1450 and $1500^{\circ} \mathrm{C}$ for $3 \mathrm{~h}$ in $\mathrm{N}_{2}$ atmosphere. The average diameter and length of the whiskers formed at $1500^{\circ} \mathrm{C}$ for $3 \mathrm{~h}$ were about $1 \mu \mathrm{m}$ and $35 \mathrm{~mm}$, respectively. The whiskers were considered to be grown by a vapor-liquid-solid mechanism.

[Received March 12, 1997; Accepted June 6, 1997]
\end{abstract}

Key-words: Whisker, SiAlON, Pyrophyllite, Reaction

1. Introduction

SiA1ON has been obtained great attention as an engineering ceramic material because of its many excellent mechanical properties. Since Jack's pioneering work, ${ }^{1)}$ its fabrication and properties have been extensively investigated. ${ }^{2), 3)}$ However, concerning the preparation of $\beta$-SiAlON whiskers which can be served as a promising reinforcing and toughening phase in fabrication of composites, only the work of Hayashi et al. was available, ${ }^{4)}$ in which, $\beta$-SiAlON whiskers was grown in the system of the $\mathrm{SiO}_{2}-\mathrm{C}-\mathrm{Na}_{3} \mathrm{AlF}_{6}$ by nitridation process. In the present paper, a new method for the synthesis of $\beta$-SiAlON whiskers is presented and the corresponding growth mechanism is discussed briefly.

\section{Experimental procedure}

The raw materials used in the present study were natural pyrophyllite and liquid resin whose typical chemical compositions are listed in Table 1. 66.66 mass\% of pyrophyllite was well mixed with 33.34 mass $\%$ of resin. The admixture was formed in a spherical sample ( $\sim 30 \mathrm{~mm}$ in diameter) and then dried at $100^{\circ} \mathrm{C}$ for $12 \mathrm{~h}$. The dried sample was placed in an alumina boat which was inserted into an electric furnace and heated at a rate of $10^{\circ} \mathrm{C} / \mathrm{min}$ to 1450 and $1500^{\circ} \mathrm{C}$ in a flowing $\mathrm{N}_{2}$ atmosphere (purity: $99.9 \%$, oxygen content: $3 \mathrm{ppm}$ ) at a rate of $0.2 \mathrm{l} / \mathrm{min}$.

The obtained whiskers were observed by optical microscopy (OM) and scanning electron microscopy (SEM), and analyzed by X-ray diffraction (XRD) and energy-dispersed spectrometry (EDS).

\section{Results and discussion}

\subsection{Features of the whisker}

Figure 1 shows OM photographs of the whiskers formed at 1450 and $1500^{\circ} \mathrm{C}$ for $3 \mathrm{~h}$, respectively. SEM observation of the whiskers formed at $1500^{\circ} \mathrm{C}$ for $3 \mathrm{~h}$ was conducted (see Fig. 2). The whiskers formed at $1450^{\circ} \mathrm{C}$ were shorter than those formed at $1500^{\circ} \mathrm{C}$ which have an average diameter

Table 1. Chemical Compositions of Raw Materials

\begin{tabular}{|c|cccccccccc|}
\hline $\begin{array}{c}\text { Chemical } \\
\text { composition }\end{array}$ & g.loss & $\mathrm{SiO}_{2}$ & $\mathrm{Al}_{2} \mathrm{O}_{3}$ & $\mathrm{Fe}_{2} \mathrm{O}_{3}$ & $\mathrm{TiO}_{2}$ & $\mathrm{CaO}$ & $\mathrm{MgO}$ & $\mathrm{Na}_{2} \mathrm{O}$ & $\mathrm{K}_{2} \mathrm{O}$ & $\mathrm{C}$ \\
\hline pyrophyllite(mass\%) & 8.53 & 48.89 & 41.69 & 0.17 & 0.25 & 0.01 & 0.01 & 0.12 & 0.07 & - \\
\hline resin (mass\%) & 50 & - & - & - & - & - & - & - & - & 50 \\
\hline
\end{tabular}

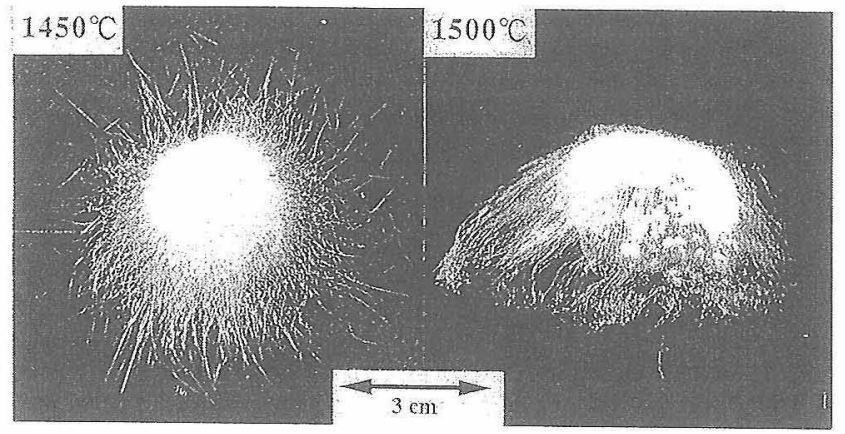

Fig. 1. Optical micrographs of $\beta$-SiAlON whiskers formed at 1450 and $1500^{\circ} \mathrm{C}$ for $3 \mathrm{~h}$ in $\mathrm{N}_{2}$, respectively.

about $1 \mu \mathrm{m}$ and the length about $35 \mathrm{~mm}$, respectively. The whiskers were confirmed to be $\beta$-SiAlON by XRD.

Figure 3 shows SEM photograph and EDS spectrum of a droplet at tip of the whisker formed at $1500^{\circ} \mathrm{C}$ for $3 \mathrm{~h}$. The droplet was composed of about 56.99 mass \% of $\mathrm{Fe}, 37.09$ mass \% of $\mathrm{Si}$ and 5.92 mass \% of $\mathrm{Al}$.

3.2 Growth mechanism

As shown in Fig. 3, the droplet contained impurity Fe was formed at the tip of the whisker, which probably suggested that the $\beta$-SiAlON whiskers were grown by the vapor-liquid-solid (VLS) mechanism, ${ }^{5)}$ as discussed below.

\subsubsection{Formation of liquid droplet}

During heating, iron oxide $\left(\mathrm{Fe}_{2} \mathrm{O}_{3}\right)$ in pyrophyllite was initially reduced by carbon derived from resin to $\mathrm{Fe}$ which further reacted with carbon to form an iron-carbon alloy $\left(\mathrm{Fe}_{x} \mathrm{C}_{y}\right)$ which, when the temperature was above its melting point (about $1153^{\circ} \mathrm{C}$ ), ${ }^{6}$ ) became a liquid droplet under the influence of surface tension.

3.2.2 Dissolution of gases in the liquid droplet

During heating, the $\mathrm{Al}_{2} \mathrm{O}_{3}(\mathrm{~s})$ and $\mathrm{SiO}_{2}(\mathrm{~s})$ containing in the pyrophyllite would react with carbon, and gaseous species would generate from the sample. According to Ref. 7, the Al- and Si-containing gases were $\mathrm{Al}(\mathrm{g}), \mathrm{Al}_{2} \mathrm{O}(\mathrm{g})$, $\mathrm{AlO}(\mathrm{g}), \mathrm{Al}_{2} \mathrm{O}_{2}(\mathrm{~g}), \mathrm{SiO}(\mathrm{g}), \mathrm{Si}(\mathrm{g}), \mathrm{Si}_{2}(\mathrm{~g}), \mathrm{Si}_{3}(\mathrm{~g})$ and $\mathrm{SiO}_{2}$ $(\mathrm{g})$, and which could be formed mainly by the following reactions.

$$
\begin{aligned}
& \mathrm{Al}_{2} \mathrm{O}_{3}(\mathrm{~s})+3 \mathrm{C}(\mathrm{s})=3 \mathrm{CO}(\mathrm{g})+2 \mathrm{Al}(\mathrm{g}) \\
& \mathrm{Al}_{2} \mathrm{O}_{3}(\mathrm{~s})+2 \mathrm{C}(\mathrm{s})=2 \mathrm{CO}(\mathrm{g})+\mathrm{Al}_{2} \mathrm{O}(\mathrm{g}) \\
& \mathrm{Al}_{2} \mathrm{O}_{3}(\mathrm{~s})+\mathrm{C}(\mathrm{s})=\mathrm{CO}(\mathrm{g})+2 \mathrm{AlO}(\mathrm{g}) \\
& \mathrm{Al}_{2} \mathrm{O}_{3}(\mathrm{~s})+\mathrm{C}(\mathrm{s})=\mathrm{CO}(\mathrm{g})+\mathrm{Al}_{2} \mathrm{O}_{2}(\mathrm{~g})
\end{aligned}
$$




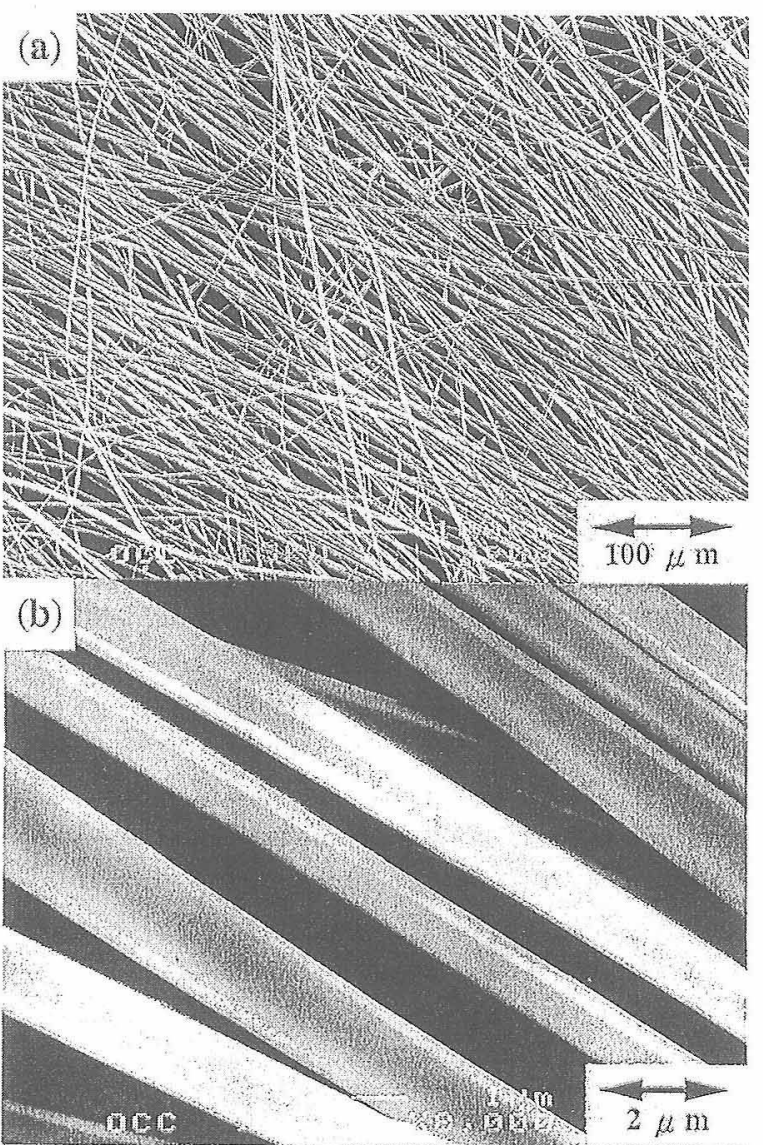

Fig. 2. SEM micrographs of $\beta$-SiAlON whiskers formed at $1500^{\circ} \mathrm{C}$ for $3 \mathrm{~h}$ in $\mathrm{N}_{2}$.

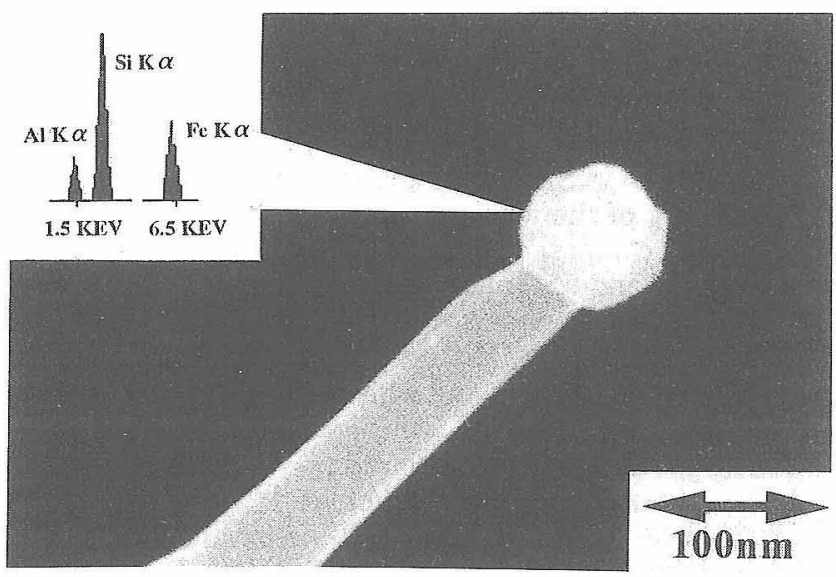

Fig. 3. SEM micrograph and EDS spectrum of a droplet at tip of the whisker formed at $1500^{\circ} \mathrm{C}$ for $3 \mathrm{~h}$ in $\mathrm{N}_{2}$.

$$
\begin{aligned}
& \mathrm{SiO}_{2}(\mathrm{~s})+\mathrm{C}(\mathrm{s})=\mathrm{CO}(\mathrm{g})+\mathrm{SiO}(\mathrm{g}) \\
& \mathrm{SiO}_{2}(\mathrm{~s})+2 \mathrm{C}(\mathrm{s})=2 \mathrm{CO}(\mathrm{g})+\mathrm{Si}(\mathrm{g}) \\
& 2 \mathrm{SiO}_{2}(\mathrm{~s})+4 \mathrm{C}(\mathrm{s})=4 \mathrm{CO}(\mathrm{g})+\mathrm{Si}_{2}(\mathrm{~g}) \\
& 3 \mathrm{SiO}_{2}(\mathrm{~s})+6 \mathrm{C}(\mathrm{s})=6 \mathrm{CO}(\mathrm{g})+\mathrm{Si}_{3}(\mathrm{~g}) \\
& \mathrm{SiO}_{2}(\mathrm{~s})=\mathrm{SiO}_{2}(\mathrm{~g})
\end{aligned}
$$

Figure 4 , as an example, shows equilibrium partial pressures of these gaseous species at $1700 \mathrm{~K}$ as a function of equilibrium partial pressure of $\mathrm{O}_{2}(\mathrm{~g})$. Considering the total pressure in the furnace being $1 \mathrm{~atm}\left(1.013 \times 10^{5} \mathrm{~Pa}\right)$, and neglecting the consumption of nitrogen during reaction process, and assuming the reaction between $\mathrm{C}(\mathrm{s})$ and $\mathrm{O}_{2}(\mathrm{~g})$ being in equilibrium, therefore the following equa-

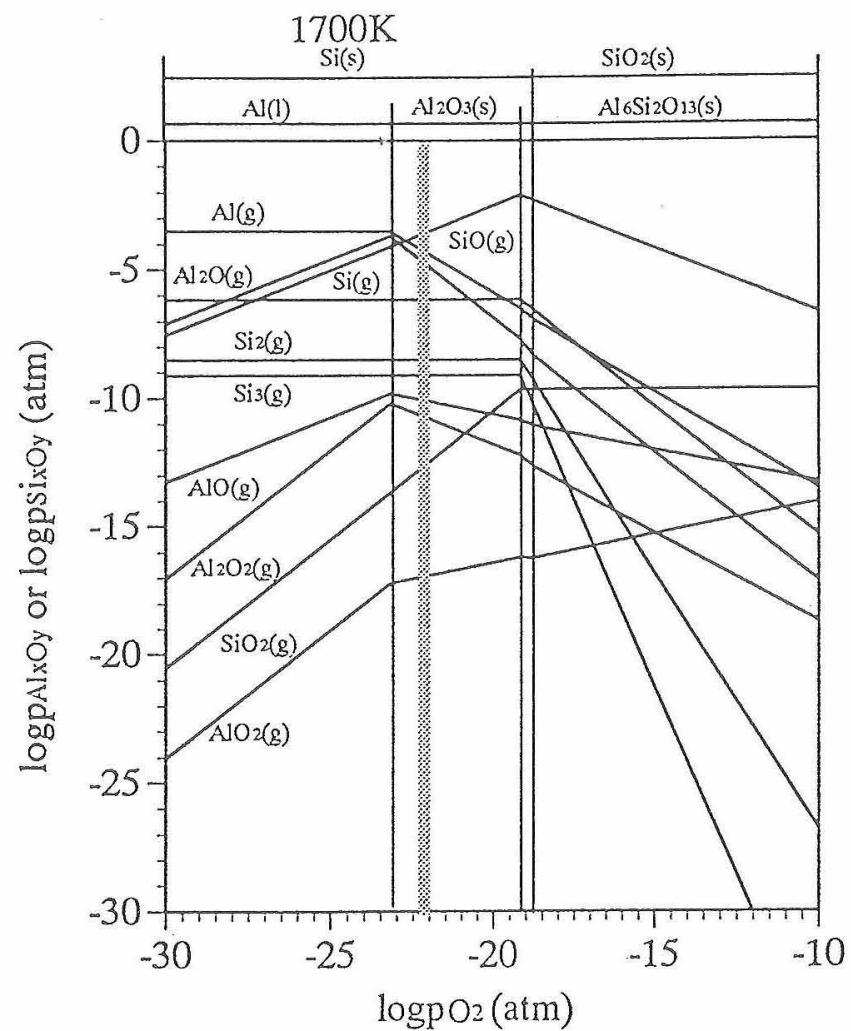

Fig. 4. Equilibrium partial pressures of gases in $\mathrm{Al}-\mathrm{Si}-\mathrm{O}$ system at $1700 \mathrm{~K}$.

tions could be established.

$$
p_{\mathrm{N}_{2}}+p_{\mathrm{i}}=1
$$

$i$-the gases showed in the Reactions (1)-(8)

$$
\begin{aligned}
& p_{\mathrm{N}_{2}}=0.999 /\left(0.999+p_{\mathrm{N}_{2}}+p_{\mathrm{i}}\right) \\
& K_{\mathrm{p}}=\left(p_{\mathrm{O}_{2}}\right)^{1 / 2} / p_{\mathrm{CO}}
\end{aligned}
$$

Based on Reactions (1) to (8) and Eqs. (10) to (12), the equilibrium partial pressure of $\mathrm{O}_{2}(\mathrm{~g})$ in the furnace could be calculated. In terms of calculation, the partial pressure of $\mathrm{O}_{2}(\mathrm{~g})$ in the furnace at $1700 \mathrm{~K}$ was about $3.80 \times 10^{-22}$ atm, at which $\mathrm{Al}(\mathrm{g}), \mathrm{Al}_{2} \mathrm{O}(\mathrm{g}), \mathrm{SiO}(\mathrm{g})$ and $\mathrm{Si}(\mathrm{g})$ showed very high partial pressures (Fig. 4 ). Therefore, once the liquid droplet was formed, these gases (and $\mathrm{N}_{2}(\mathrm{~g})$ ) would dissolve into the droplet.

3.2.3 Growth of $\beta$-SiAION whiskers from the droplet

When the liquid droplet became supersaturated with the gases stated above, the whiskers would grow by precipitation of $\beta$-SiAlON from the liquid (according to, for example, Reactions (13) and (14), where [i] indicates i gas dissolved in the droplet)

$$
\begin{aligned}
& 3[\mathrm{SiO}]+3[\mathrm{Al}]+(5 / 2)\left[\mathrm{N}_{2}\right]=\mathrm{Si}_{3} \mathrm{Al}_{3} \mathrm{O}_{3} \mathrm{~N}_{5}(\mathrm{~s}) \\
& 3[\mathrm{Si}]+3\left[\mathrm{Al}_{2} \mathrm{O}\right]+3[\mathrm{SiO}]+5\left[\mathrm{~N}_{2}\right] \\
& \quad=2 \mathrm{Si}_{3} \mathrm{Al}_{3} \mathrm{O}_{3} \mathrm{~N}_{5}(\mathrm{~s})
\end{aligned}
$$

\section{Summary}

Synthesis of $\beta$-SiA1ON whiskers from pyrophyllite was investigated and the growth of the whiskers was explained by VLS (vapor-liquid-solid) mechanism. During heating, $\mathrm{Fe}_{2} \mathrm{O}_{3}$ in pyrophyllite was reduced by carbon derived from resin to $\mathrm{Fe}$ which further reacted with $\mathrm{C}$ to form an alloy $\left(\mathrm{Fe}_{x} \mathrm{C}_{y}\right)$. When the temperature was above the melting point of the alloy (about $1153^{\circ} \mathrm{C}$ ), the alloy would become a liquid droplet under the influence of surface tension. Once the droplet was formed, the gases such as $\mathrm{Si}(\mathrm{g}), \mathrm{SiO}(\mathrm{g})$, $\mathrm{Al}(\mathrm{g}), \mathrm{Al}_{2} \mathrm{O}(\mathrm{g})$ and $\mathrm{N}_{2}(\mathrm{~g})$ would dissolve into the droplet. When the liquid droplet became supersaturated with the gases, the whiskers would grow by precipitation of $\beta$ - 
SiAlON from the liquid.

\section{References}

1) K. H. Jack, J. Mater. Sci., 11, 1135-58 (1976).

2) H. Yoshimatsu, H. Kawasaki, Y. Miura and A. Osaka, J. Mater. Sci, 24, 3280-84 (1989).

3) H. L. Lee, H. J. Lim, S. Kim and H. B. Lee, J. Am. Ceram. Soc., 72, 1458-61 (1989).

4) T. Hayashi, S. Kawabe and H. Saito, Yogyo-Kyokai-Shi, 94,
19-25 (1986).

5) R. S. Wagner and W. C. Ellis, Appl. Phys. Lett., 4, 89-90 (1964).

6) Hand Book of Metals, Ed. by the Japan Institute of Metals, Tokyo (1990) p. 509.

7) M. W. Chase, Jr., C. A. Davies, J. R. Downey, Jr., D. J. Frurip, R. A. McDonald and A. N. Syverud, Vol. 14, Ed. by the American Chemical Society and the American Institute of Physics for the National Bureau of Standards (1985). 